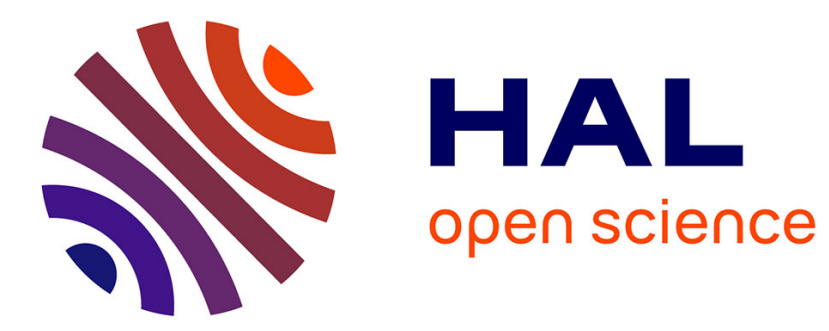

\title{
N2-fixing trees and the transfer of fixed-N for sustainable agroforestry: a review
}

\author{
Jake Munroe, Marney Isaac
}

\section{To cite this version:}

Jake Munroe, Marney Isaac. N2-fixing trees and the transfer of fixed-N for sustainable agroforestry: a review. Agronomy for Sustainable Development, 2014, 34 (2), pp.417-427. 10.1007/s13593-013-01905. hal-01234810

\author{
HAL Id: hal-01234810 \\ https://hal.science/hal-01234810
}

Submitted on 27 Nov 2015

HAL is a multi-disciplinary open access archive for the deposit and dissemination of scientific research documents, whether they are published or not. The documents may come from teaching and research institutions in France or abroad, or from public or private research centers.
L'archive ouverte pluridisciplinaire HAL, est destinée au dépôt et à la diffusion de documents scientifiques de niveau recherche, publiés ou non, émanant des établissements d'enseignement et de recherche français ou étrangers, des laboratoires publics ou privés. 


\title{
$\mathbf{N}_{2}$-fixing trees and the transfer of fixed-N for sustainable agroforestry: a review
}

\author{
Jake W. Munroe • Marney E. Isaac
}

Accepted: 8 October 2013 /Published online: 15 November 2013

(C) INRA and Springer-Verlag France 2013

\begin{abstract}
Many tropical areas lack soil nitrogen (N), an essential nutrient for plant growth and the production of food. Commercial $\mathrm{N}$ fertilisers are expensive, with only a fraction of this nutrient reaching the plant, which limits efficiency and potentially increases water contamination. Dinitrogen $\left(\mathrm{N}_{2}\right)$-fixing trees are a promising alternative to sustainably fertilise crops. The use of $\mathrm{N}_{2}$-fixing trees in tropical agriculture has garnered attention from researchers, development organisations, governments, and farmers in recent years as a revival of pro-environmental practices. Dinitrogen $\left(\mathrm{N}_{2}\right)$-fixing trees can establish in N-deficient soils, replace $\mathrm{N}$ lost in harvest and provide an as-of-yet not fully realised benefit to ecosystem services. High $\mathrm{N}_{2}$-fixation rates, upwards of $92 \%$, have been measured in some $\mathrm{N}_{2}-$ fixing trees, using the ${ }^{15} \mathrm{~N}$ natural abundance method. The recovery of this fixed-N by associated perennial crops is of particular interest in tropical agroforestry systems. Here, we review $\mathrm{N}$ transfer pathways from trees to perennial crops in agroforestry. We focus on Theobroma cacao and Coffea arabica. We also draw on agroforestry systems with herbaceous alleys. We identify three pathways of $\mathrm{N}$ transfer from $\mathrm{N}_{2}$-fixers to non- $\mathrm{N}_{2}$-fixing crops: (1) decomposition and mineralisation of organic compounds, e.g., litter, prunings, roots, and nodules, (2) root-to-root direct transfer via exudation, and (3) common mycorrhizal networks. Both ${ }^{15} \mathrm{~N}$ natural abundance and ${ }^{15} \mathrm{~N}$ enrichment techniques have been used to study $\mathrm{N}$ transfer. However, various factors limit
\end{abstract}

J. W. Munroe $\cdot$ M. E. Isaac

Department of Geography, University of Toronto,

Toronto, Ontario, Canada

M. E. Isaac ( $₫)$

Department of Physical and Environmental Sciences and the Center for Critical Development Studies, University of Toronto Scarborough, 1265 Military Trail, M1C 1A4 Toronto, Canada e-mail: marney.isaac@utoronto.ca the accuracy of estimates within agroforestry systems. Under field conditions, the major limits are (1) improper reference selection and (2) unrepresentative sampling of the receiver plant and/or donor $\mathrm{N}$ source. We highlight key findings and provide recommendations to tackle these obstacles.

Keywords Agriculture and biodiversity - Coffea arabica . $\mathrm{N}_{2}$-fixing trees $\cdot{ }^{15} \mathrm{~N}$ natural abundance $\cdot{ }^{15} \mathrm{~N}$ isotopic dilution · Root exchange $\cdot$ Theobroma cacao $\cdot$ Tropical agroforestry

Content

1. Introduction: $\mathrm{N}_{2}$-fixing trees

2. Measuring $\mathrm{N}_{2}$-fixation

2.1 Methodological considerations

2.2 Rates of $\mathrm{N}_{2}$-fixation

3. The transfer of fixed-N

3.1 Methodological considerations

3.2 Measuring $\mathrm{N}$ transfer

3.3 Nitrogen transfer pathways

3.3.1 Decomposition and mineralisation of organic compounds

3.3.2 Root to root transfer

3.3.3 Common mycorrhizal networks

4. Other determinants of $\mathrm{N}_{2}$-fixation and $\mathrm{N}$ transfer

5. Current challenges

6. Conclusions

\section{Introduction: $\mathbf{N}_{\mathbf{2}}$-fixing trees}

The incorporation of dinitrogen $\left(\mathrm{N}_{2}\right)$-fixing trees within tropical agriculture has garnered attention from researchers, development organisations, governments, and farmers as a revival of pro-environmental agricultural management 
practice. Trees within agricultural landscapes, or agroforestry systems, have been shown to reduce erosion, increase biodiversity, and restore and maintain soil fertility (Danso et al. 1992; Nair et al. 1998; Schroth et al. 2001, 2004; Isaac et al. 2007; Kurppa et al. 2010; Isaac and Kimaro 2011). Dinitrogen-fixing trees can replace nitrogen $(\mathrm{N})$ lost in harvest, possess the unique ability to establish in N-deficient soils, and provide as of yet not fully realised benefits to ecosystem services (Kurppa et al. 2010; Araujo et al. 2012; Jensen et al. 2012; Nygren et al. 2012). Numerous studies have estimated $\mathrm{N}_{2}$-fixation rates and quantified $\mathrm{N}$ inputs in agroforestry systems (Beer et al. 1998; Rowe et al. 1999; Nygren et al. 2000; Isaac et al. 2012). However, in recent years, efforts have been made to quantify the specific benefits to associated herbaceous and woody non-fixing crops. In doing so, the utility of $\mathrm{N}_{2}$-fixing trees within agroforestry systems can be more clearly justified in terms of the nutrient economy via $\mathrm{N}$ deposition and the monetary economy via ecosystem services.

While $\mathrm{N}_{2}$-fixation occurs across all biomes, $\mathrm{N}$-fixing trees are found in much greater proportions across tropical latitudes (Houlton et al. 2008). Over 650 woody biological $\mathrm{N}_{2}$-fixing species exist, of which 515 are leguminous; the majority of $\mathrm{N}_{2}$-fixing trees species used in tropical agroforestry are legumes, with the exception of several genera of actinorrhizal trees, such as Alnus spp. and Casuarina spp. (Nair et al. 1998). The range of $\mathrm{N}_{2}$-fixation capacity varies greatly amongst these trees (Beer et al. 1998; Giller 2001). Annually, $\mathrm{N}_{2}$-fixation may add from tens to hundreds of kilograms of $\mathrm{N}$ per hectare to an agroforestry system as pointed by Nygren et al. (2012) in their review. The most popular $\mathrm{N}_{2}$-fixing trees used in tropical agroforestry systems include the legumes Acacia spp., Erythrina spp., Gliricidia spp., Inga spp., and Leucena spp., which form symbiotic associations with a wide variety of $\mathrm{N}_{2}$-fixing bacterial species (Bala et al. 2003).

Multistrata agroforestry systems are tree-crop-based land use systems with two or more vegetation layers that include more than one tree species (Schroth et al. 2001). Tree-crops common in such systems include coffee, cacao, oil palm, coconut, fruit trees, rubber, and tea, thus holding tremendous global economic importance. The incorporation of a tree as an over-storey serves a variety of purposes, which include light regulation, enhanced nutrient and water cycling, organic matter accumulation, pest regulation, and, when $\mathrm{N}_{2}$-fixing trees are used, $\mathrm{N}$ inputs to the system (Fig. 1). Coffee (Coffea arabica) and cacao (Theobroma cacao) are particularly economically important woody perennial crops (Nygren et al. 2012). Combined, they are grown on 21.6 Mha of agricultural land globally (FAOStat 2011) and are often intercropped with $\mathrm{N}_{2}$-fixing trees within multistrata systems (Schroth et al. 2001; Nygren et al. 2012). According to some estimates that also account for $\mathrm{N}$ exported in harvest and accumulated in crop biomass, many common $\mathrm{N}_{2}$-fixing trees reportedly fix sufficient $\mathrm{N}$ to meet current and potentially increasing $\mathrm{N}$ needs of these species (Nygren et al. 2012).

This review paper is motivated by the questions: (1) do $\mathrm{N}_{2}-$ fixing trees provide a significant and reliable source of $\mathrm{N}$ to associated perennial crops, particularly coffee and cacao, in agroforestry systems, (2) how does transfer of fixed-N occur from legume tree to perennial crop, and (3) do appropriate and accurate techniques exist to determine this transfer from $\mathrm{N}_{2}-$ fixing tree to perennial crop? We review recent work specific to woody perennial crops within agroforestry systems, and draw upon research on systems with non-woody perennial and annual crops. We review literature in terms of $\mathrm{N}_{2}$-fixation capacity in common woody leguminous agroforestry species and in terms of modes of transfer, particularly dominant pathways in $\mathrm{N}_{2}$-fixing tree and perennial crop systems. While the fate of biologically fixed-N has recently been reviewed (Nygren et al. 2012), we emphasise the methodological challenges associated with the quantification of $\mathrm{N}$ transfer between $\mathrm{N}_{2}$-fixing trees and recipient woody perennial crops in particular. Finally, we evaluate how one can mitigate uncertainty in $\mathrm{N}_{2}$-fixation and transfer measurements in the field within these important agroforestry systems.

\section{Measuring $\mathbf{N}_{2}$-fixation}

As in plant ecological research as a whole (Dawson et al. 2002), stable isotope techniques have been used to advance
Fig. 1 The perennial crop coffee (C. arabica) a with no $\mathrm{N}_{2}$-fixing trees in foreground and under agroforestry with the $\mathrm{N}_{2}$-fixing tree Chloroleucon eurycyclum in the background and $\mathbf{b}$ under the $\mathrm{N}_{2}$-fixing tree E. poeppigiana. These $\mathrm{N}_{2}$-fixing trees contribute light regulation as well as an undetermined amount of $\mathrm{N}$ to the economically important coffee
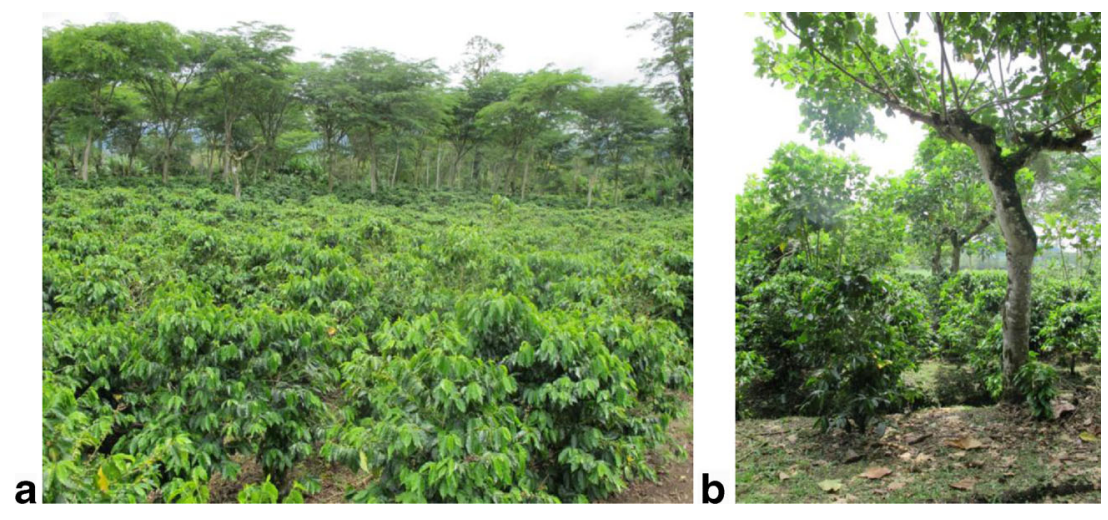
knowledge of $\mathrm{N}$ dynamics within terrestrial ecosystems. Two dominant methods are used to measure $\mathrm{N}_{2}$-fixation: (1) natural abundance and (2) isotopic dilution (Unkovich et al. 2008). Insights as to the nature of $\mathrm{N}_{2}$-fixation are gained by using stable isotopes at naturally occurring levels. Nitrogen-15 $\left({ }^{15} \mathrm{~N}\right)$, the rare and heavy isotope of $\mathrm{N}$, represents a constant $0.3663 \%$ (Dawson et al. 2002) of the $\mathrm{N}_{2}$ in the atmosphere but exists in a range of abundances within soil (typically slightly enriched) (Danso et al. 1992; Martinelli et al. 1999). By comparison with an absolute abundance ratio (derived from atmospheric $\mathrm{N}$ ), experimenters can obtain a delta $(\delta)$ ${ }^{15} \mathrm{~N}$ value (Martinelli et al. 1999; Dawson et al. 2002). A positive $\delta^{15} \mathrm{~N}$ value is indicative of a sample enriched in ${ }^{15} \mathrm{~N}$ relative to natural abundance, whereas a negative $\delta^{15} \mathrm{~N}$ indicates a lesser proportion of the heavy ${ }^{15} \mathrm{~N}$ (Dawson et al. 2002). Furthermore, small $\delta^{15} \mathrm{~N}$ values, when compared with a non- $\mathrm{N}_{2}$-fixing reference plant with larger $\delta^{15} \mathrm{~N}$, reflect the enrichment of the available soil $\mathrm{N}$, and can be used to quantify percentage $\mathrm{N}$ derived from atmosphere by $\mathrm{N}_{2}$-fixing plants via the natural abundance method.

Though initially applied in agricultural settings to herbaceous legumes, the natural abundance method has been used for $\mathrm{N}_{2}$-fixing trees in tropical agroforestry systems (Snoeck et al. 2000; Nygren and Leblanc 2009; Isaac et al. 2011). The use of a suitable reference plant (a physiologically similar, but non- $\mathrm{N}_{2}$-fixing, tree that acquires soil $\mathrm{N}$ within the same environment) provides an isotopic signature representative of purely soil-derived $\mathrm{N}$. The reference plant, along with the isotopic signature of the $\mathrm{N}_{2}$-fixer grown in $\mathrm{N}$-free media entirely dependent upon $\mathrm{N}_{2}$-fixation, provides a means of comparison by which to quantify percent $\mathrm{N}$ derived from atmosphere. Unlike whole-plant sampling that can be performed with herbaceous legumes, representative tissue samples of mature $\mathrm{N}_{2}$-fixing trees must be analysed to determine ${ }^{15} \mathrm{~N}$ isotopic signature (Dawson et al. 2002). A significant difference between the $\delta^{15} \mathrm{~N}$ value of the $\mathrm{N}_{2}$-fixing trees tissue and the equivalent tissue type of a reference tree is necessary for the natural abundance method to be applied successfully. Typically, this occurs when the isotopic signature of the available soil $\mathrm{N}$ is much greater than that of atmospheric $\mathrm{N}$.

The ${ }^{15} \mathrm{~N}$ isotope dilution technique was used to assess $\mathrm{N}_{2-}$ fixation rates more widely prior to the development of the natural abundance method (Unkovich et al. 2008). It is useful in situations in which $\delta^{15} \mathrm{~N}$ of plant-available $\mathrm{N}$ is too low or high-precision mass-spectrometry is unavailable (Unkovich et al. 2008). Isotope dilution uses the same premise as the natural abundance method, except that soil is artificially enriched in ${ }^{15} \mathrm{~N}$ above background levels. ${ }^{15} \mathrm{~N}$-enriched fertilisers are used, and the reduction of the proportion of ${ }^{15} \mathrm{~N}$ in a fixing plant is compared with that of a nonfixer (Unkovich et al. 2008). Issues arise in terms of achieving even (spatial and temporal) distribution of the ${ }^{15} \mathrm{~N}$-enriched plantavailable mineral $\mathrm{N}$, as well growing plants with similar rooting patterns. Similar to the natural abundance methods, one of the main weaknesses of the technique is the need to use non- $\mathrm{N}_{2}$-fixing plants to assess legume ${ }^{15} \mathrm{~N}$ uptake (Unkovich et al. 2008). However, in a recent comparison of isotope dilution and natural abundance, Bouillet et al. (2008) determined that dilution can give more reliable estimates of tree $\mathrm{N}_{2}$-fixation rates.

\subsection{Methodological considerations}

A number of unique challenges exist for both the natural abundance and isotopic dilution methods. Firstly, when employing the natural abundance method to quantify $\mathrm{N}_{2}$ fixation in woody perennial plants, samples from which isotopic signatures are determined may not be representative of the entire plant. Isotopic fractionation and variability among the organs of individual trees exists (Nygren et al. 2012), with the highest $\delta^{15} \mathrm{~N}$ typically found in leaves (Boddey et al. 2000). Whole plant sampling is preferable, though with mature, large trees this is rarely possible. Multiple tissue types can be used (Nygren and Leblanc 2009), though mature leaves are most common. In addition, some researchers have found a way around this by using juvenile trees. Secondly, similar rooting patterns and phenology between the reference plant and the $\mathrm{N}_{2}$-fixing tree is required to ensure the use of the same source of soil N. Recent work has shown support for reference plant selection that neighbours the $\mathrm{N}_{2}$-fixer over a reference plant in pure stands due to the influence of the $\mathrm{N}_{2}$-fixer on the ${ }^{15} \mathrm{~N}$ signature of the soil $\mathrm{N}$ (Carlsson and Huss-Danell 2013). Boddey et al. (2000) contend that selection of a reference tree that obtains soil $\mathrm{N}$ according to the same temporal and spatial patterns of an $\mathrm{N}_{2}$ fixing tree can be difficult. In fact, the authors recommend that a variety of reference plants should be used to ensure an accurate estimation of percent $\mathrm{N}$ derived from atmosphere. This ecological and physiological similarity between $\mathrm{N}_{2}$ fixing trees and non- $\mathrm{N}_{2}$-fixing reference species is critical for accurate estimates of $\mathrm{N}_{2}$-fixation (Unkovich et al. 2008). Thirdly, long-term growth patterns and changes over time in $\mathrm{N}_{2}$-fixation potential make it difficult to generalise data, as evidenced by the declining $\mathrm{N}_{2}$-fixation rates of Acacia senegal with age (Isaac et al. 2011). Large plant-to-plant variation in growth rate and degree of nodulation exists (Boddey et al. 2000), and this may be particularly pronounced in managed agroforestry systems. Finally, as it is rarely possible to harvest entire trees or shrubs, quantification of $\mathrm{N}$ input by $\mathrm{N}_{2}$-fixation on an annual per area basis requires estimation based upon tree parameters. Estimates of annual growth and production, which are necessary to make estimates of total contributions of $\mathrm{N}_{2}$-fixation, can be problematic. A greater reliance on accurate allometric relationships could be used to scale up $\mathrm{N}_{2}$-fixation values to predict total contribution at the individual scale. 


\subsection{Rates of $\mathrm{N}_{2}$-fixation}

The amount of $\mathrm{N}$ fixed by $\mathrm{N}_{2}$-fixing trees in agroforestry systems is quite variable; values are affected by climate, soil characteristics, mycorrhizal status (Barea et al. 1987; Nygren et al. 2012) and management factors, such as nutrient inputs, pruning frequency/intensity, and tree physiology. Dinitrogen fixation estimates for a variety of tree species commonly used in agroforesty systems have been comprehensively reviewed by Nygren et al. (2012), in which the authors present percentage $\mathrm{N}$ derived from atmosphere values that vary greatly, from a low of $5 \%$ for Calliandra calothyrsus (Ståhl et al. 2002) to a high of $92 \%$ for Gliricidia sepium (Nygren et al. 2000), depending upon sampling time. Dulormne et al. (2003) determined that G. sepium planted at a density of 13 , 000 trees $^{-1}$ fixed $147 \mathrm{~kg} \mathrm{~N} \mathrm{ha}^{-1}$ year $^{-1}$ within a cut-andcarry silvopastoral system. In a Burundian shade coffee system, percent $\mathrm{N}$ derived from the atmosphere for three different $\mathrm{N}_{2}$-fixing trees ranged from 20 to $48 \%$ (Snoeck et al. 2000). Under humid tropical conditions, two $\mathrm{N}_{2}$-fixing trees, G. sepium and Inga edulis, were found to derive 85$86 \%$ and $74-81 \% \mathrm{~N}$ derived from atmosphere, respectively (Kurppa et al. 2010). Soil P, along with tree age, has been shown to effect $\mathrm{N}_{2}$-fixation within agroforestry systems. Isaac et al. (2011) found higher rates of $\mathrm{N}_{2}$-fixation in natural populations of $A$. senegal when the supply of soil $\mathrm{P}$ was not limiting. Additionally, percent $\mathrm{N}$ derived from atmosphere was on average $18 \%$ greater in saplings compared with mature trees (Isaac et al. 2011).

Our understanding of $\mathrm{N}_{2}$-fixation within actual agroforestry systems is impacted by the limitations and accuracy of the methodologies employed; a theme that will persist throughout this paper. Nevertheless, qualitative and quantitative evidence exists to support the utility of $\mathrm{N}_{2}$-fixer tree incorporation in tropical agroforestry.

\section{The transfer of fixed-N}

The potential for $\mathrm{N}_{2}$-fixing trees to enhance fertility within perennial-crop agroforestry systems is clear (Nygren et al. 2012); transfer of fixed-N to associated crops, however, is not always guaranteed (Dommergues 1995). The study of $\mathrm{N}$ transfer between $\mathrm{N}_{2}$-fixing plants (donors) and non- $\mathrm{N}_{2}$-fixing crops (receivers) in perennial crop agroforestry systems is crucial to understanding how best to meet crop $\mathrm{N}$ requirements with reduced external inputs ( $\mathrm{He}$ et al. 2009). Of particular interest is perennial, and importantly tree-, crop recovery of the $\mathrm{N}$ fixed by neighbouring $\mathrm{N}_{2}$-fixing trees. Dinitrogen fixation and $\mathrm{N}$ transfer have been researched extensively within temperate grasslands, particularly in perennial pastures (Elgersma et al. 2000; Paynel et al. 2001; Gylfadóttir et al. 2007; Pirhofer-Walzl et al. 2011), in which both the $\mathrm{N}_{2}$-fixing and non- $\mathrm{N}_{2}$-fixing plants are herbaceous. While the study of $\mathrm{N}_{2}$-fixation and $\mathrm{N}$ transfer within tropical agroforestry has predominately drawn upon methodologies originally developed for temperate agriculture, the unique spatial arrangement and morphological characteristics of perennial crops and $\mathrm{N}_{2}$-fixing trees within agroforestry systems present unique challenges for conceptualising, as well as (sampling and) measuring, the fate of fixed-N.

\subsection{Methodological considerations}

Stable $\mathrm{N}$ isotope techniques can also be used to trace or quantify transfer of $\mathrm{N}$ from one plant to another. Given the sensitivity to fractionation of ${ }^{15} \mathrm{~N}$ within the plant-soil system, the use of natural abundance as a tracer is difficult; many studies instead rely upon isotope enrichment (Dawson et al. 2002). Labelling by leaf feeding has been the most common enrichment method applied to the study of $\mathrm{N}$ transfer within agroforestry systems (Sierra et al. 2007). As with other enrichment methods (Dawson et al. 2002), trace amounts of a label (enriched with the heavier isotope) are applied topically to the leaf tissue and subsequently taken into the plant's vascular system. The use of a label drastically minimises the influence of ${ }^{15} \mathrm{~N}$ fractionation by amplifying the signal (Dawson et al. 2002). There have been issues, however, in using the technique with leguminous trees (Sierra and Daudin 2010). As Jalonen and Sierra (2012) assert, ${ }^{15} \mathrm{~N}$ labelling may result in differential enrichment in different tree parts. The widespread use of juvenile trees in greenhouse studies (Rao and Giller 1993; Jalonen et al. 2009a; Kurppa et al. 2010; Isaac et al. 2012) has been encouraged by the difficulty encountered in labelling large, mature trees via leaf feeding. While such experiments have yielded important findings regarding quantity and mechanisms of transfer, the degree to which they represent actual $\mathrm{N}$ dynamics in the field remains questionable.

While ${ }^{15} \mathrm{~N}$ labelling is more common, the ${ }^{15} \mathrm{~N}$ natural abundance method has also been applied to estimating $\mathrm{N}$ transfer from $\mathrm{N}_{2}$-fixing trees to perennial crops. Although detection of transferred $\mathrm{N}$ may be limited, the technique negates the need for a ${ }^{15} \mathrm{~N}$ label to be added to the soil or plant and allows for transfer to be studied in situ, without disturbing the plant-soil system.

\subsection{Measuring $\mathrm{N}$ transfer}

Several studies (e.g., Snoeck et al. 2000; Sierra and Nygren 2006; Nygren and Leblanc 2009) have used isotopic techniques to estimate transfer in a variety of exclusively perennial crop agroforestry systems. Two principal equations have been published to calculate the amount of $\mathrm{N}$ transferred, the results of which are reported as slightly different "units." These are: (1) the percent $\mathrm{N}$ transferred to the recipient plant in 
relation to the amount of fixed-N by the $\mathrm{N}_{2}$-fixing tree (Snoeck et al. 2000) or (2) the proportion of $\mathrm{N}$ derived from transfer per total N of recipient plant (Sierra and Nygren 2006; Jalonen et al. 2009a). We present a summary of these somewhat rare studies, including: the $\mathrm{N}_{2}$-fixing tree involved and its function in the agroforestry system, the recipient perennial crop (predominately woody perennials - coffee and cocoa- but also a perennial grass), the source of reference values, the type of experiment, and the estimation method including a reference to type of calculation (1 or 2) described above (Table 1). Data summarised in this table is referred to in the subsequent sections on fixed-N pathways when discussing specifically perennial to perennial transfer.

\subsection{Nitrogen transfer pathways}

Currently, acknowledged pathways identified using ${ }^{15} \mathrm{~N}$ isotopic techniques include: decomposition and mineralisation of donor organic matter, such as leaves, branches, roots, and nodules (Haggar et al. 1993; Sierra and Nygren 2006); release and subsequent uptake of $\mathrm{N}$-rich donor exudates (Paynel et al. 2001; Jalonen et al. 2009b); and transfer by common mycorrhizal networks (He et al. 2009; Jalonen et al. 2009b) (Fig. 2). The proportion of $\mathrm{N}$ transferred by each of these modes varies across agroecosystems and is affected by management practices. Despite the significance of $\mathrm{N}$ transfer from $\mathrm{N}_{2}$-fixing tree to non- $\mathrm{N}_{2}$-fixing crops within tropical agroforestry systems, much is yet to be learned regarding the various mechanisms at play.

Throughout this section, a consistent set of terminology will be used to categorise pathways of $\mathrm{N}$ transfer. Aboveground transfer will refer exclusively to decomposition and mineralisation of aboveground biomass of the $\mathrm{N}_{2}$-fixing tree (e.g., leaf litter and branch prunings); additionally, it is considered an "indirect" mode of transfer. Belowground transfer will refer to any process that occurs solely in the soil. Indirect, belowground transfer includes decomposition and mineralisation of dead roots and nodules; direct transfer, on the other hand, refers to uptake of $\mathrm{N}$ by the recipient plant without transformation of the $\mathrm{N}$ source (e.g., via common mycorrhizal networks and/or via root exudation) (Fig. 2). Each mode plays a role in the $\mathrm{N}$ economy of agroforestry systems, and unique temporal and spatial considerations must be made when considering how to elucidate their relative importance under a particular set of environmental and management conditions.

\subsubsection{Decomposition and mineralisation of organic compounds}

Early research in tropical agroforestry systems focused on transfer of $\mathrm{N}$ via decomposition and mineralisation of leaf litter and prunings. Haggar et al. (1993) used ${ }^{15} \mathrm{~N}$ labeling of pruning residues to demonstrate a $10 \%$ contribution by $\mathrm{N}_{2}$ fixing trees Erythrina poeppigiana and G. sepium to total maize $\mathrm{N}$ within an alley cropping system. Maize grown without $\mathrm{N}_{2}$-fixing tree mulch contained 3-15\% less $\mathrm{N}$ at maturity. Furthermore, increased pools of soil organic $\mathrm{N}$ and more rapid mineralisation under alley cropping led the authors to suggest that high organic inputs from $\mathrm{N}_{2}$-fixing trees may enhance on-going transfer that is unaccounted for in shortterm studies. Snoeck et al. (2000) used the natural ${ }^{15} \mathrm{~N}$ abundance method at field sites in Burundi and found a range of $13-42 \%$ of $\mathrm{N}$ transferred (in terms of total $\mathrm{N}$ fixed by the $\mathrm{N}_{2}$-fixing tree) to the tree-crop, coffee (Table 1). A positive relationship was found between $\mathrm{N}_{2}$-fixation capacity of the $\mathrm{N}_{2}$-fixing tree and percentage of $\mathrm{N}$ derived from transfer in the associated tree crop. This study demonstrated, via ${ }^{15} \mathrm{~N}$ enrichment of $\mathrm{N}_{2}$-fixing tree-derived mulch, that approximately $75 \%$ of fixed-N was transferred via mineralisation of aboveground mulch. Several experimental procedures, however, call into question the accuracy of these findings. The use of leaf sampling (for both donor and receiver plants) may have skewed transfer estimates due to unrepresentative sample ${ }^{15} \mathrm{~N}$ signatures. In addition, fractionation within the soil-plant system, of which our knowledge is limited (Dawson et al. 2002), was not comprehensively accounted for.

\subsubsection{Root to root transfer}

Research on $\mathrm{N}$ transfer via belowground pathways within agroforestry systems has been sparse due to methodological difficulties. Observations within both greenhouse and in-field studies have made its importance evident. In a four week pot study, Rao and Giller (1993) found rates of 3.07-3.87 \% N transfer from leguminous tree (Leucaena diversifolia) to grass (Cenchrus ciliaris). The transfer of $\mathrm{N}$ without aboveground litter in this study demonstrated a belowground pathway for $\mathrm{N}$ transfer from $\mathrm{N}_{2}$-fixer to non- $\mathrm{N}_{2}$-fixer. In a field study on a cut-and-carry silvopastoral system, Sierra and Nygren (2006) used ${ }^{15} \mathrm{~N}$ natural abundance to show that approximately one third of $\mathrm{N}$ in the grass was of atmospheric origin, despite the removal of $\mathrm{N}_{2}$-fixing tree prunings and leaf litter. In previous studies on the same site (Sierra et al. 2002; Dulormne et al. 2003), however, it was determined that decomposition of tree litter, roots, and nodules accounted for only one third of belowground $\mathrm{N}$ transfer within the system. This unaccounted for transfer of $\mathrm{N}$ served to motivate the further investigation of belowground mechanisms.

Belowground, short-term transfer of $\mathrm{N}$ through root exudation from herbaceous legumes to pasture grasses (Paynel et al. 2001) provided clues for understanding unaccounted for transfer in agroforestry systems. Nitrogen transfer by root exudation occurs when nitrogenous, low molecular weight compounds are exuded by living roots of 


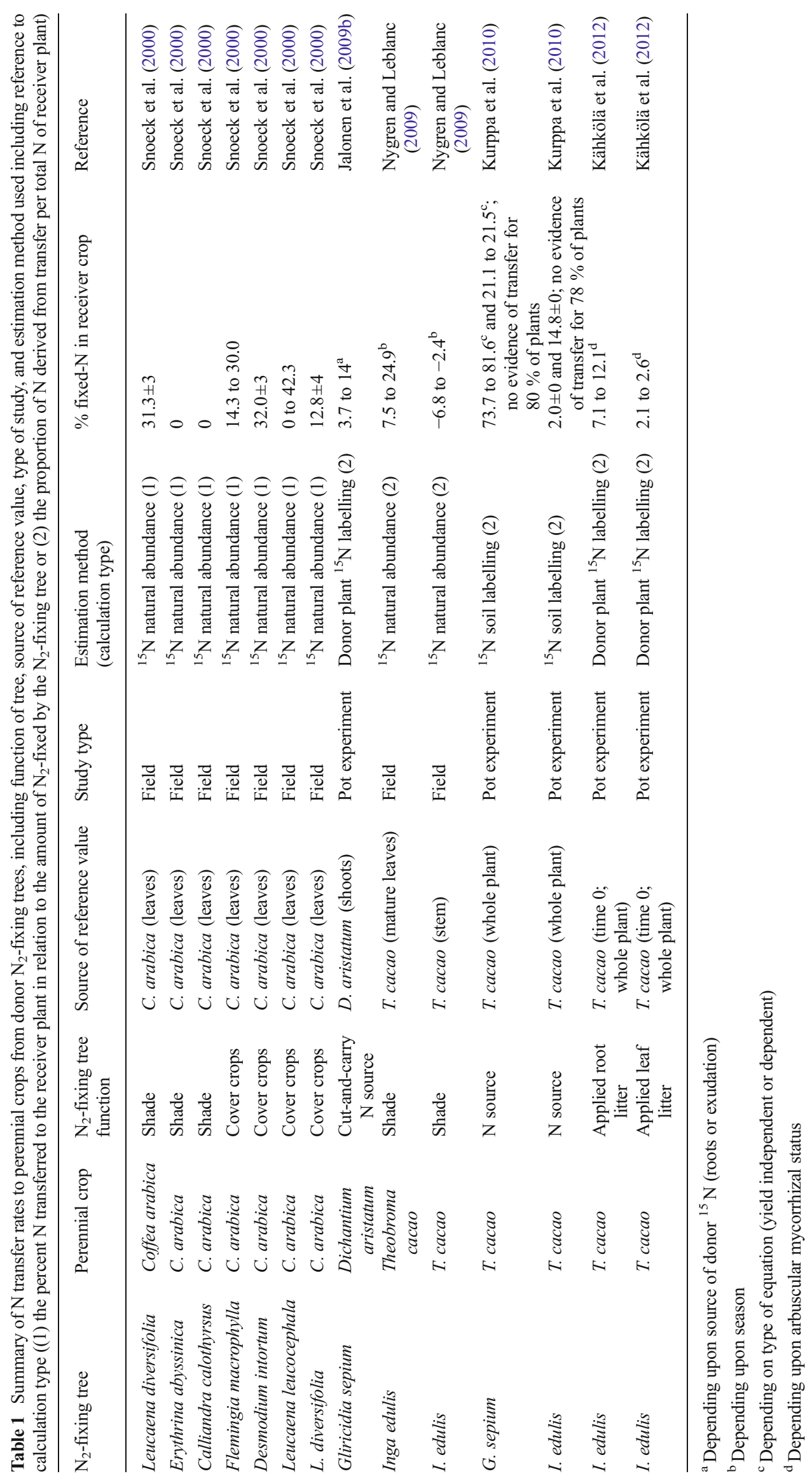



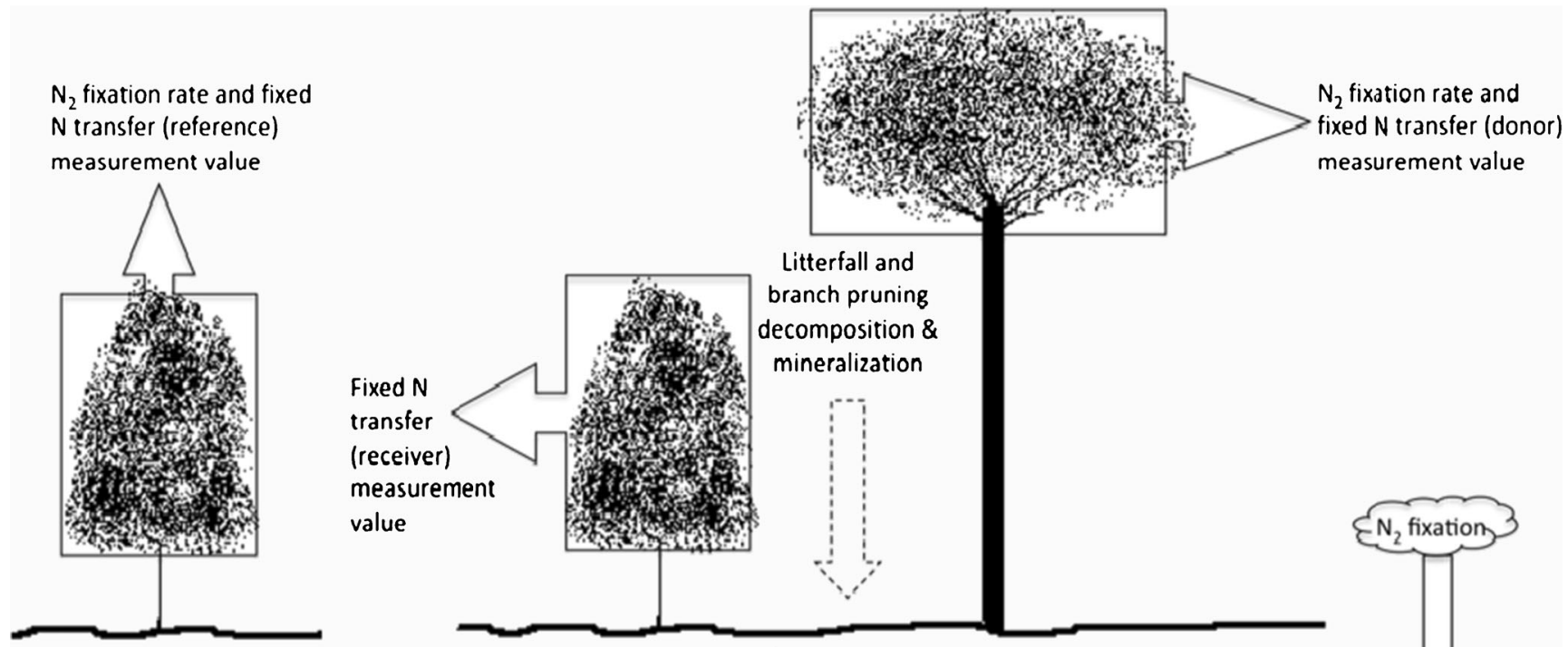

Litterfall and

branch pruning

decomposition \&

mineralization
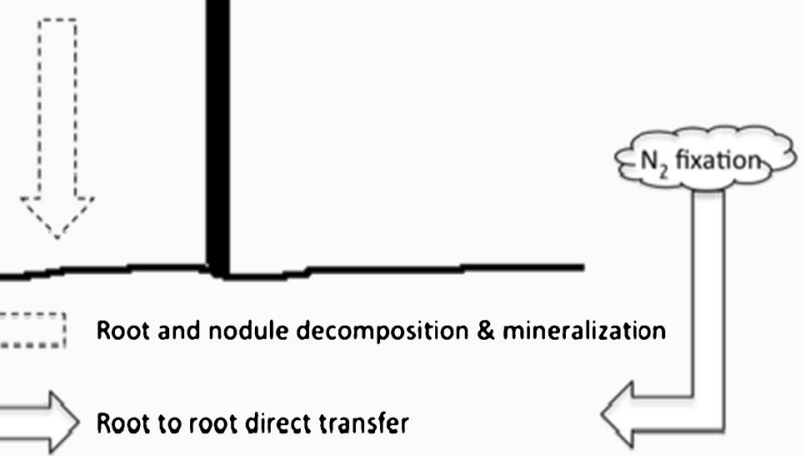

Root to root direct transfer

Mycorrhizal networks

Fig. 2 A schematic of the $\mathrm{N}$ transfer pathways in agroforestry systems with $\mathrm{N}_{2}$-fixing trees (donor) and perennial crops (receiver). Solid arrows represent direct pathways and dashed arrows represent indirect pathways. Boxes with arrows represent sources of values for calculations

$\mathrm{N}_{2}$-fixers and subsequently taken up by associated plants (Jalonen et al. 2009a). Paynel et al. (2001) found $95 \%$ of $\mathrm{N}$ in root exudates of white clover to be in the form of ammonium; exudates also include amino acids such as glycine and serine, which, like ammonium, can be absorbed without prior mineralisation (Jalonen et al. 2009a). Given the potential for transfer of these compounds, $\mathrm{N}$ transfer via root exudation has been studied within a variety of tropical agroforestry systems.

Exudates have been shown to represent a significant proportion of $\mathrm{N}$ transferred within the aforementioned tropical silvopastoral system. In a greenhouse study of G. sepium, a tropical $\mathrm{N}_{2}$-fixing tree, and Dichantium aristatum, its associated $\mathrm{C}_{4}$ grass, Jalonen et al. (2009b) used ${ }^{15} \mathrm{~N}$ enrichment via foliar feeding to study $\mathrm{N}$ transfer. The researchers measured a daily $\mathrm{N}$ exudation of $0.07-0.12 \%$ of tree total $\mathrm{N}$, and compared the isotopic $\delta^{15} \mathrm{~N}$ signature of both exudates and roots (of G. sepium) to that of grass shoots. During a 10-week experiment, the grass absorbed an estimated $22 \%$ of $\mathrm{N}$ exuded by $G$. sepium and $\mathrm{N}$ transfer of 3.7 up to $14 \%$ (using $\delta^{15} \mathrm{~N}$ of tree roots and tree exudates as a reference, respectively) of grass $\mathrm{N}$ was attributed to exudation (Jalonen et al. 2009b; Table 1). It is important to note that juvenile trees were used, which is of concern as $\mathrm{N}_{2}$-fixation in trees has been shown to decrease with age (Isaac et al. 2011). of $\mathrm{N}_{2}$-fixation rates and fixed-N transfer, including the source of reference values. Although the receiver crop is represented as a tree crop (i.e., coffee and cocoa), perennial grasses could also be the receiver crop in perennial crop agroforestry systems

However, $\delta^{15} \mathrm{~N}$ was measured throughout the experiment to account for dilution of the signal. Nitrogen transfer via exudation was isolated in this study by assuming that tree root decomposition was insignificant during the experimental period, as it was in a rapid growth phase.

The study of $\mathrm{N}$ transfer between $\mathrm{N}_{2}$-fixing shade trees and cacao has arguably been less successful in quantifying and differentiating between modes of belowground transfer. Kurppa et al. (2010) used soil isotopic enrichment to investigate the transfer of $\mathrm{N}$ from G. sepium and Inga edulis, leguminous shade trees, to cacao (T. cacao) saplings under semi controlled conditions in the field (experiment in barrels). Leaf litter production during the eight month experiment in the Caribbean coastal plain of Costa Rica was negligible; thus all transfer of fixed-N was attributed to belowground transfer. $\mathrm{N}$ transfer was calculated by using ${ }^{15} \mathrm{~N}$-enriched cacao grown alone as a reference against which intercropped cacao was compared. No evidence of transfer, however, was detected in the majority $(80 \%)$ of the study's associations (Kurppa et al. 2010) (Table 1), and differentiation between root exudation and decomposition of root matter was not made. Plant root zones were restricted by barrels in which they were grown in the field to contain the ${ }^{15} \mathrm{~N}$ soil label, and the authors cite that root competition may have limited transfer of $\mathrm{N}$ (Kurppa et al. 2010). In addition, juvenile plants were once again used, and 
may not have been representative (in terms of $\mathrm{N}_{2}$-fixation and exudation) of mature trees within the system. Whole plant harvesting was performed, however, to determine $\delta^{15} \mathrm{~N}$ of all plants, as root-shoot partitioning of ${ }^{15} \mathrm{~N}$ was detected. This study highlights the challenges of investigating $\mathrm{N}$ transfer in situ, both in terms of differentiating between mechanisms and maintaining growth conditions similar to those in the field.

\subsubsection{Common mycorrhizal networks}

Common mycorrhizal networks represent a route of direct $\mathrm{N}$ transfer between species across a variety of ecosystems and managed agricultural systems. Arbuscular mycorrhizal fungi form symbiotic associations with over $80 \%$ of all terrestrial plants (Jalonen et al. 2009b), including most tropical trees and crop plants such as coffee and cacao (Kähkölä et al. 2012). They infect root cortex cells and receive photosynthetically fixed carbon in exchange for nutrients, water, and protection from pathogens (Leigh et al. 2009). Arbuscular mycorrhizal fungi have low host specificity, and as such, an individual fungus can form associations with multiple plants of different species (He et al. 2009; Jalonen et al. 2009b). Furthermore, carbon and nutrients have been shown to flow through common mycorrhizal networks between different plant species (Jalonen et al. 2009b). In particular, common mycorrhizal networks have been found to mediate transfer of inorganic $\mathrm{N}$ from $\mathrm{N}_{2}$-fixing species to non- $\mathrm{N}_{2}$-fixing species (Moyer-Henry et al. 2006). In 1988, Haystead et al. first confirmed that mycorrhizal inoculation could enhance $\mathrm{N}$ transfer between plants. Since that study, which was on white clover and perennial ryegrass, research within pasture systems - and more recently agroforestry systems - has focussed on uncovering the extent to which common mycorrhizal networks transfer $\mathrm{N}$.

Within an agroforestry context, while numerous studies (Rao and Giller 1993; Nygren and Leblanc 2009; Isaac et al. 2012) have suggested the involvement of mycorrhizalmediated transfer, the only known experiment to quantify contribution by common mycorrhizal networks is the aforementioned greenhouse study by Jalonen et al. (2009b). In an additional treatment, ${ }^{15} \mathrm{~N}$-labelled G. sepium and $D$. aristatum were grown together with their root systems separated by a fine polyester mesh that allowed fungal hyphae, but not roots, to pass through (Jalonen et al. 2009b). The physical characteristics of the clayey soil (identical to that found in the field) used did not allow for substantial horizontal flow of water or nutrients, and thus all $\mathrm{N}$ transfer was attributable to transfer via fungal hyphae (Jalonen et al. $2009 b)$. Nitrogen transfer of $0.7-2.5 \%$ of grass total $\mathrm{N}$ was detected in the treatment. Also, grass shoot subsample $\delta^{15} \mathrm{~N}$ signatures were used in the calculations, as they were independently confirmed to be representative of the signature of the entire grass biomass. Interestingly, lower grass root $\mathrm{N}$ concentration was positively correlated with increased $\mathrm{N}$ transfer by mycelia, as was increased mycorrhizal colonisation of tree roots with proportion of tree total $\mathrm{N}$ transferred (Jalonen et al. 2009b). This, the authors suggest, indicates a source-sink dynamic between the plants-an observation that has been noted in the study of pastures (Simard et al. 2003).

When the proportion of $\mathrm{N}$ transferred by mycorrhizal fungi has been detected, it has been small. In many systems, however, this pathway has not yet been quantitatively isolated. In the study by Kurppa et al. (2010), despite colonisation between $T$. cacao and $I$. edulis by the same arbuscular mycorrhizal morphospecies (Nygren and Leblanc 2009), direct $\mathrm{N}$ transfer was not correlated with mycorrhizal colonisation of donor or receiver plant roots. These authors proposed that common mycorrhizal networks may not have formed within the time frame of their experiment and that transfer by root exudation may have been a more important pathway (Kurppa et al. 2010). Indeed, this would agree with the findings of Jalonen et al. (2009b). It was also suggested that intense competition for soil resources within limited space may have shifted the flow of $\mathrm{N}$ in common mycorrhizal networks (if they existed) towards the faster growing leguminous tree (Kurppa et al. 2010).

Despite the difficulty in studying direct transfer by common mycorrhizal networks, and the relatively small role they likely play, recent research suggests that arbuscular mycorrhizal fungi can transfer substantial $\mathrm{N}$ to their host plant from organic material (Leigh et al. 2009). This holds important implications regarding the ability of crops to take up $\mathrm{N}$ from decomposing litter of $\mathrm{N}_{2}$-fixing plants. Kähkölä et al. (2012) found that arbuscular mycorrhizal fungi inoculation of cacao saplings improved $\mathrm{N}$ uptake from $I$. edulis leaf litter by $0.5 \%$ and root litter by $5 \%$ (Table 1 ). Trees are known to act as reservoirs for mycelial networks for short-lived crops (Ingleby et al. 2007), and tree-based cropping systems can support a more abundant and diverse arbuscular mycorrhizal fungi community (Bainard et al. 2011). Therefore, overall arbuscular mycorrhizal fungi contributions to $\mathrm{N}$ transfer in agroforestry systems may be more important than direct transfer via common mycorrhizal networks. This is certainly an area that warrants further study.

\section{Other determinants of $\mathrm{N}_{2}$-fixation and $\mathrm{N}$ transfer}

As we have established, $\mathrm{N}$ is transferred from $\mathrm{N}_{2}$-fixing tree species to associated non- $\mathrm{N}_{2}$-fixers via a variety of indirect and direct pathways. These pathways include decomposition and mineralisation of aboveground litter and belowground nodules and root tissue, direct root-to-root transfer by exudation, and direct transfer by mycelial connections (Fig. 2). Many different conditions affect the dynamics and 
magnitude of $\mathrm{N}$ transfer, which is demonstrated by the wide range of quantitative estimates cited within this review. Such conditions include precipitation and soil texture, availability of other key nutrients, as well as plant species type and spacing-some of which can be directly or indirectly influenced by management practices. Further consideration of these environmental conditions is necessary to gain a better ability to predict the magnitude of $\mathrm{N}$ transfer within managed systems.

Given the control exerted by environmental factors such as temperature and moisture on $\mathrm{N}_{2}$-fixation (Danso et al. 1992) and decomposition and mineralisation processes, such environmental factors should also influence $\mathrm{N}$ transfer. The most comprehensive analysis of climatic factors controlling $\mathrm{N}$ transfer within tropical agroforestry was performed on the previously mentioned silvopastoral system. Daudin and Sierra (2008) determined rainfall and evapotranspiration to be the main climatic factors controlling transfer. Both affected the rate of $\mathrm{N}$ release and the ability of the grass to uptake it (Daudin and Sierra 2008). Through the use of climatic data and modelling, it was estimated that an increase of $10 \%$ precipitation/day would induce a $14 \%$ increase in $\mathrm{N}$ coming from the tree and a $10 \%$ rise in grass $\mathrm{N}$ uptake (Daudin and Sierra 2008). Within this particular system, findings suggest that during more favourable periods for $\mathrm{N}$ mineralisation, soil $\mathrm{N}$ may compensate for reduced transferred $\mathrm{N}$. The soil type ( $80 \%$ clay rich in smectite) was also considered in this study, and was postulated to encourage preferential uptake of tree- $\mathrm{N}$ due to its tight adsorption of soil ammonium. Though broad, these findings provide clues as to role of climate and soil type in shaping $\mathrm{N}$ transfer dynamics.

\section{Current challenges}

Several factors have the potential to limit the accuracy of $\mathrm{N}$ transfer measurement within perennial based agroforestry systems. The adeptness of the researcher's experimental design determines the precision with which $\mathrm{N}$ transfer via distinct pathways can be differentiated. The most reliable data available regarding $\mathrm{N}$ transfer is derived from studies whose methodology cleverly distinguishes transfer and effectively accounts for and/or controls limiting factors. Such factors include, but are not limited to: skewing of $\delta^{15} \mathrm{~N}$ isotopic signatures by fractionation within the soil-plant system (if natural abundance tracing is used); $\delta^{15} \mathrm{~N}$ signatures derived from tissue samples that are unrepresentative of the whole receiver plant; donor plant $\delta^{15} \mathrm{~N}$ tissue signatures unrepresentative of (the particular form of) $\mathrm{N}$ being transferred and; dilution of ${ }^{15} \mathrm{~N}$ label and/or partitioning in donor tissue over time.

Additionally, the appropriate selection of a reference source and $\delta^{15} \mathrm{~N}$ value to use in calculations of $\mathrm{N}_{2}$-fixation rates or $\mathrm{N}$ transfer rates remains a challenge (Carlsson and Huss-Danell 2013). For instance, charting the effects on $\mathrm{N}_{2}$-fixation and $\mathrm{N}$ transfer values by maximising reference plant physiological similarity while sacrificing environmental similarity, or vice versus, is required. Furthermore, recent work by Jalonen and Sierra (2012), which found that fractions of $\mathrm{N}_{2}$-fixing tree residue have unique $\delta^{15} \mathrm{~N}$ values based upon their $\mathrm{C} / \mathrm{N}$ ratios, exemplifies the detailed inquiry needed to obtain accurate $\mathrm{N}$ transfer estimates. They demonstrate the stochastic nature of $\delta^{15} \mathrm{~N}$; using mathematical models, ${ }^{15} \mathrm{~N}$ patterns of the recipient plants were accurately simulated only when at least two fractions of residue with distinct $\delta^{15} \mathrm{~N}$ signatures were included. This reveals a much more complex nature of $\operatorname{root} \mathrm{N}$, and highlights the advantage of considering distinct fractions of donor tissue when estimating $\mathrm{N}$ transfer rates. We recommend more use of mixed models in the development of $\mathrm{N}$ transfer calculations. Finally, as pointed out above, more than one equation is used to calculate $\mathrm{N}$ transfer rates and final percentages are represented, predominately, in two ways (as a percent of recipient plant total $\mathrm{N}$ or as a percent of donor plant $\mathrm{N}_{2}$-fixation rate). We suggest that a more consistent mode of presenting $\mathrm{N}$ transfer values is needed and based on our review, find that the percent of recipient plant total $\mathrm{N}$ derived from atmospheric source is seemingly the most used and more logical mode.

\section{Conclusions}

Nitrogen transfer from $\mathrm{N}_{2}$-fixing trees to perennial crops within low-input tropical agroforestry systems represents an appealing source of nutrient replacement. Research efforts, which have followed on the heels of related work in temperate pasture grasslands, have employed stable isotope techniques to study the dynamics of $\mathrm{N}$ transfer. Indirect transfer, through the mineralisation and subsequent uptake of $\mathrm{N}$ from leaf litter, branches, and root tissue, appears to be the major pathway in tropical agroforestry systems, especially where the aboveground biomass of tree legume is recycled to the soil. Contribution by exclusively belowground and potentially more direct mechanisms, however, is increasingly recognised. Exudation of N-rich molecules from $\mathrm{N}_{2}$-fixing plants and subsequent uptake by closely associated root systems represents a smaller, but substantial pathway. Lastly, common mycorrhizal networks constitute the smallest mode of transfer, and one that continues to be difficult to quantify. The investigation of $\mathrm{N}$ transfer dynamics in agroforestry systems with perennial crops, however, has only just begun. Given their importance globally, along with the economic vulnerability associated with dependence upon $\mathrm{N}$ fertiliser, such research deserves high priority. 
Acknowledgements The authors would like to acknowledge financial support from the Natural Sciences and Engineering Research Council of Canada. The authors thank anonymous reviewers for insightful and constructive comments on the manuscript.

\section{References}

Araujo ASF, Leite LFC, Iwata BF, Lira MA, Xavier GR, Figueiredo MVB (2012) Microbiological process in agroforestry systems. A review. Agron Sustain Dev 32:215-226. doi:10.1007/s13593-011-0026-0

Bainard LD, Klironomos JN, Gordon AM (2011) Arbuscular mycorrhizal fungi in tree-based intercropping systems: A review of their abundance and diversity. Pedobiol Int J Soil Biol 54:57-61. doi: 10.1016/j.pedobi.2010.11.001

Bala A, Murphy PJ, Osunde AO, Giller KE (2003) Nodulation of tree legumes and ecology of their native rhizobial populations in tropical soils. Appl Soil Ecol 22:211-223. doi:10.1016/S0929-1393(02) 00157-9

Barea JM, Azcon-Aguilar C, Azcon R (1987) Vesicular-arbuscular mycorrhiza improve both symbiotic $\mathrm{N}_{2}$ fixation and $\mathrm{N}$ uptake from soil as assessed with a ${ }^{15} \mathrm{~N}$ technique under field conditions. New Phytol 106:717-725. doi:10.1111/j.1469-8137.1987.tb00172.x

Beer J, Muschler R, Kass D, Somarriba E (1998) Shade management in coffee and cacao plantations. Agrofor Syst 7:103-114. doi:10.1007/ 978-94-015-9008-2 6

Boddey RM, Peoples MB, Palmer B, Dart PJ (2000) Use of the ${ }^{15} \mathrm{~N}$ natural abundance technique to quantify biological nitrogen fixation by woody perennials. Nutr Cycl Agroecosyst 57:235-270. doi:10. 1023/A:1009890514844

Bouillet JP, Laclau JP, Gonçalves JLM, Moreira MZ, Trivelin PCO, Jourdan C, Silva EV, Piccolo MC, Tsai SM, Galiana A (2008) Mixed-species plantations of Acacia mangium and Eucalyptus grandis in Brazil: 2: Nitrogen accumulation in the stands and biological N2 fixation. For Eco Manage 255:3918-3930. doi:10. 1016/j.foreco.2007.10.050

Carlsson G, Huss-Danell K (2013) Does nitrogen transfer between plants confound ${ }^{15} \mathrm{~N}$-based quantifications of $\mathrm{N}_{2}$ fixation? Plant Soil. doi: 10.1007/s11104-013-1802-1

Danso SKA, Bowen GD, Sanginga N (1992) Biological nitrogen fixation in trees in agro-ecosystems. Plant Soil 141:177-196. doi:10.1007/ 978-94-017-0910-1_10

Daudin D, Sierra J (2008) Spatial and temporal variation of below-ground $\mathrm{N}$ transfer from a leguminous tree to an associated grass in an agroforestry system. Agric Ecosyst Environ 126:275-280. doi:10. 1016/j.agee.2008.02.009

Dawson TE, Mambelli S, Plamboeck AH, Templer PH, Tu KP (2002) Stable isotopes in plant ecology. Annu Rev Ecol Syst 33:507-559. doi:10.1146/annurev.ecolsys.33.020602.095451

Dommergues YR (1995) Nitrogen fixation by trees in relation to soil nitrogen economy. Fertil Res 42:215-230. doi:10.1007/ BF00750516

Dulormne M, Sierra J, Nygren P, Cruz P (2003) Nitrogen-fixation dynamics in a cut-and-carry silvopastoral system in the subhumid conditions of Guadeloupe, French Antilles. Agrofor Syst 59:121129. doi:10.1023/A:1026387711571

Elgersma A, Schlepers H, Nassiri M (2000) Interactions between perennial ryegrass (Lolium perenne L.) and white clover (Trifolium repens L.) under contrasting nitrogen availability: productivity, seasonal patterns of species composition, $\mathrm{N}_{2}$ fixation, $\mathrm{N}$ transfer and N recovery. Plant Soil 21:281-299. doi:10.1023/ A:1004797106981

FAOStat (2011) http://www.fao.org/corp/statistics/en/. Accessed on 15 March 2013
Giller KE (2001) Nitrogen fixation in tropical cropping systems, 2nd edn. CABI Publishing, Wallingford

Gylfadóttir T, Helgadóttir A, Høgh-Jensen H (2007) Consequences of including adapted white clover in northern European grassland: transfer and deposition of nitrogen. Plant Soil 297:93-104. doi:10. 1007/s11104-007-9323-4

Haggar JP, Tanner EVJ, Beer JW, Kass DCL (1993) Nitrogen dynamics of tropical agroforestry and annual cropping systems. Soil Biol Biochem 25:1363-1378. doi:10.1016/0038-0717(93)90051-C

Haystead A, Malajczuk N, Grove TS (1988) Underground transfer of nitrogen between pasture plants infected with vesicular-arbuscular mycorrhizal fungi. New Phytol 108:417-423. doi:10.1111/j.14698137.1988.tb04182.x

He X, Xu M, Qiu GY, Zhou J (2009) Use of ${ }^{15} \mathrm{~N}$ stable isotope to quantify nitrogen transfer between mycorrhizal plants. J Plant Ecol 2:107118. doi:10.1093/jpe/rtp015

Houlton BZ, Wang YP, Vitousek PM, Field CB (2008) A unifying framework for dinitrogen fixation in the terrestrial biosphere. Nature 454:327-330. doi:10.1038/nature07028

Ingleby K, Wilson J, Munro RC, Cavers S (2007) Mycorrhizas in agroforestry: spread and sharing of arbuscular mycorrhizal fungi between trees and crops: complementary use of molecular and microscopic approaches. Plant Soil 294:125-136. doi:10.1007/ s11104-007-9239-z

Isaac ME, Kimaro AA (2011) Diagnosis of nutrient imbalances with vector analysis in agroforestry systems. J Environ Qual 40:860 866. doi:10.2134/jeq2010.0144

Isaac ME, Timmer VR, Quashie-Sam SJ (2007) Shade tree effects in an 8year-old cocoa agroforestry system: biomass and nutrient diagnosis of Theobroma cacao by vector analysis. Nutr Cycl Agroecosyst 78: 155-165. doi:10.1007/s10705-006-9081-3

Isaac ME, Harmand JM, Lesueur D, Lelon J (2011) Tree age and soil phosphorus conditions influence $\mathrm{N}_{2}$-fixation rates and soil $\mathrm{N}$ dynamics in natural populations of Acacia senegal. For Ecol Manag 261:582-588

Isaac ME, Hinsinger P, Harmand JM (2012) Nitrogen and phosphorus economy of a legume tree-cereal intercropping system under controlled conditions. Sci Total Environ. doi:10.1016/j.scitotenv. 2011.12.071

Jalonen R, Sierra J (2012) Temporal variation of N isotopic composition of decomposing legume roots and its implications to $\mathrm{N}$ cycling estimates in ${ }^{15} \mathrm{~N}$ tracer studies in agroforestry systems. Appl Environ Soil Sci Artic. doi:10.1155/2012/506302, ID 506302

Jalonen R, Nygren P, Sierra J (2009a) Root exudates of a legume tree as a nitrogen source for a tropical fodder grass. Nutr Cycl Agroecosyst 85:203-213. doi:10.1007/s10705-009-9259-6

Jalonen R, Nygren P, Sierra J (2009b) Transfer of nitrogen from a tropical legume tree to an associated fodder grass via root exudation and common mycelial networks. Plant Cell Environ 32:1366-1376. doi: 10.1111/j.1365-3040.2009.02004.x

Jensen ES, Peoples MB, Boddey RM, Gresshoff PM, Hauggaard-Nielsen $\mathrm{H}$, Alves BJR, Morrison MJ (2012) Legumes for mitigation of climate change and the provision of feedstock for biofuels and biorefineries - a review. Agron Sustain Dev 32:329-364. doi:10. 1007/s13593-011-0056-7

Kähkölä A-K, Nygren P, Leblanc HA, Pennanen T, Pietikäinen J (2012) Leaf and root litter of a legume tree as nitrogen sources for cacaos with different root colonisation by arbuscular mycorrhizae. Nutr Cycl Agroecosyst 92:51-65. doi:10.1007/s10705-011-9471-z

Kurppa M, Leblanc HA, Nygren P (2010) Detection of nitrogen transfer from $\mathrm{N}_{2}$-fixing shade trees to cacao saplings in ${ }^{15} \mathrm{~N}$ labelled soil: ecological and experimental considerations. Agrofor Syst 80:223239. doi:10.1007/s10457-010-9327-6

Leigh J, Hodge A, Fitter AH (2009) Arbuscular mycorrhizal fungi can transfer substantial amounts of nitrogen to their host plant from 
organic material. New Phytol 181:199-207. doi:10.1111/j.14698137.2008.02630.x

Martinelli LA, Piccolo MC, Townsend AR, Vitousek PM, Cuevas E, McDowell W, Robertson GP, Santos OC, Treseder K (1999) Nitrogen stable isotopic composition of leaves and soil: tropical versus temperate forests. Biogeochem 46:45-65. doi:10.1007/ BF01007573

Moyer-Henry KA, Burton JW, Israel DW, Rufty TW (2006) Nitrogen transfer between plants: a ${ }^{15} \mathrm{~N}$ natural abundance study with crop and weed species. Plant Soil 282:7-20. doi:10.1007/s11104-0053081-y

Nair PKR, Buresh RJ, Mugendi DN, Latt CR (1998) Nutrient cycling in tropical agroforestry systems: myths and science. In: Buck LE, Lassoie JP, Fernandes ECM (eds) Agroforestry in sustainable agriculture. CRC Press, Boca Raton, pp 1-32

Nygren P, Leblanc HA (2009) Natural abundance of ${ }^{15} \mathrm{~N}$ in two cacao plantations with legume and non-legume shade trees. Agrofor Syst 76:303-315. doi:10.1007/s10457-008-9160-3

Nygren P, Cruz P, Domenach AM, Vaillant V, Sierra J (2000) Influence of forage harvesting regimes on dynamics of biological dinitrogen fixation of a tropical woody legume. Tree Physiol 20:41-48

Nygren P, Fernández MP, Harmand J-M, Leblanc HA (2012) Symbiotic dinitrogen fixation by trees: an underestimated resource in agroforestry systems? Nutr Cycl Agroecosyst. doi:10.1007/s10705-012-9542-9

Paynel F, Murray PJ, Cliquet JB (2001) Root exudates: a pathway for short-term N transfer from clover and ryegrass. Plant Soil 229:235243. doi:10.1023/A:1004877214831

Pirhofer-Walzl K, Rasmussen J, Høgh-Jensen H, Eriksen J, Søegaard K, Rasmussen J (2011) Nitrogen transfer from forage legumes to nine neighbouring plants in a multi-species grassland. Plant Soil. doi:10. 1007/s11104-011-0882-z

Rao AV, Giller KE (1993) Nitrogen fixation and its transfer from Leucaena to grass using ${ }^{15}$ N. N For Ecol Manag 61:221-227

Rowe EC, Hairiah K, Giller KE, van Noordwijk M, Cadisch G (1999) Testing the safety-net role of hedgerow trees by ${ }^{15} \mathrm{~N}$ placement at different soil depths. Agrofor Syst 43:81-93
Schroth G, Lehmann J, Rodrigues MRL, Barros E, Macêdo JLV (2001) Plant-soil interactions in multistrata agroforestry in the humid tropics. Agrofor Syst 53:85-102

Schroth G, da Fonseca GAB, Harvey CA, Gascon C, Vasconcelos HL, Izac A-MN (2004) Agroforestry and biodiversity conservation in tropical landscapes. Island Press, Washington

Sierra J, Daudin D (2010) Limited ${ }^{15} \mathrm{~N}$ transfer from stem-labeled leguminous trees to associated grass in an agroforestry system. Eur J Agron 32:240-242. doi:10.1016/j.eja.2009.11.003

Sierra J, Nygren P (2006) Transfer of N fixed by a legume tree to the associated grass in a tropical silvopastoral system. Soil Biol Biochem 38:1893-1903. doi:10.1016/j.soilbio.2005.12.012

Sierra J, Dulormne M, Desfontaines L (2002) Soil nitrogen as affected by Gliricidia sepium in a silvopastoral system in Guadeloupe, French Antilles. Agrofor Syst 54:87-97. doi:10. 1023/A:1015025401946

Sierra J, Daudin D, Domenach A, Nygren P, Desfontaines L (2007) Nitrogen transfer from a legume tree to the associated grass estimated by the isotopic signature of tree root exudates: a comparison of the ${ }^{15} \mathrm{~N}$ leaf feeding and natural ${ }^{15} \mathrm{~N}$ abundance methods. Eur J Agron 27:178-186. doi:10.1016/j. eja.2007.03.003

Simard SW, Durali D, Jones M (2003) Carbon and nutrient fluxes within and between mycorrhizal plants. Ecol Stud 157:33-74. doi:10.1007/ 978-3-540-38364-2 2

Snoeck D, Zapata F, Domenach A-M (2000) Isotopic evidence of the transfer of nitrogen fixed by legumes to coffee trees. Biotechnol Agron Soc Environ 4:95-100

Ståhl L, Nyberg G, Högberg P, Buresh RJ (2002) Effects of planted tree fallows on soil nitrogen dynamics aboveground and root biomass, $\mathrm{N}_{2}$-fixation and subsequent maize crop productivity in Kenya. Plant Soil 243:103-117

Unkovich M, Herridge D, Peoples M, Cadisch G, Boddey R, Giller KE, Alves B, Chalk P (2008) Measuring plant-associated nitrogen fixation in agricultural systems. ACIAR, Canberra, Australia, 258 p. http://aciar.gov.au/publication/MN136 